\title{
A vén EuRóPA IFJÚSÁGA
}

\author{
CSEPELI GYÖRGY
}

\author{
Eötvös Loránd Tudományegyetem Társadalomtudományi Kar \\ Institute of Advanced Studies Köszeg
}

A cikk az európai társadalmakra váró 21. századi kihívásokkal foglalkozik, melyekre az európai fiataloknak kell megtalálniuk a választ. Európa demográfiai és gazdasági súlya a világban folyamatosan csökken. A bevándorlás várhatóan teljesen megváltoztatja a földrész kulturális jellegét. A Kelet-Nyugat különbség azonban nem csökken. A magyar fiatalok előnyben részesítik a teljesítmény értékét, szemben európai kortársaikkal, akik inkább az altruizmus iránt elkötelezettek. Az európai egységesülés kulcskérdése a közös nyelv és az európai identitás, mely nem tagadja, hanem kiegészíti a nemzeti identitást. Az európai identitás kialakításának feltétele az egységes európai politikai szocializáció.

Kulcsszavakः európai identitás, globális kihívások, európai politikai szocializáció

The paper deals with the challenges of 21 st century to the European societies. These challengers must be responded by the European youth. The demographic and economic weight of Europe in the worlds is diminishing. Immigration will change the cultural character of Europe completely. The divide, however, between East and West will remain unchanged. As opposed to the European youth Hungarian young men and women prefer achievement while youngsters living in the rest of Europe are most committed to universalism. The key question of the of the European common experience is the common language and the building of European identity. There will be no European Identity without a common practice of European political socialisation.

Keywords: European identity, global challenges, European political socialization

\footnotetext{
$\mathrm{A}$ kvatummechanika világa és a társadalom alkotta világ egyívású abban, hogy egyik sem ismerhető meg konvencionálisan. A megfigyelő van csak, aki ha eltünik, eltünik vele a világ is, melyet megfigyelt. Szerencse, hogy megfigyelő bőven van, így a hit, hogy ami nincs, de mégis csak van, sosem tűnik el. Újra meg újra jönnek emberek, akik folytatják, amit elődeik abbahagytak.

Európa kiváltképpen kitüntetett példája a megismerési bizonytalanságoknak. Ha valami biztosat akarunk állítani róla, akkor csak annyit mondhatunk, hogy Európa föníciai királylány volt, akit Zeusz megszeretett, s három fiút nemzett tőle, köztük Minószt, a
} 
híres-hírhedt krétai királyt. Minósz hütlen felesége szülte az emberevő szörnyeteget, Minótauroszt, akit Theszeusz, athéni királyfi ölt meg a krétai király knosszoszi palotájába épített labirintusban.

A mítosz többet mond Európáról, mint megannyi földrajzi, történeti, kulturális és politikatudományi elemzés. A kulturális antropológia nyelvén azt mondhatjuk, hogy Európa helyzete liminális. A meghatározhatatlan és megismerhetetlen földrész, mely Európa nevét viseli, sem nem földi, sem nem égi létező. Egyetlen lényegi jellemzője a szabadság (Gyurgyák 2018).

A második világháború után a franciák és a németek úgy döntöttek, hogy elég volt a háborúzásból. Egyetértett velük a három Benelux állam és Olaszország. Szerződések során át fokozatosan épült ki az együttmüködés, mely az országok egyre nagyobb körét fogta át. Ma már az Európai Uniónak 28 tagja van. A létszám 2019-ben 27-re csökkenhet, ha Nagy-Britannia elhagyja a közösséget. Az együttműködés tartós békét hozott Európa országaira. Az Európai Unión belül megnyíltak a határok, az emberek, az eszmék, az áruk szabadon áramolhatnak.

$\mathrm{A} z$ Európai Unióban élő emberek körében egyre inkább tért hódít a nemzeti és az európai identitás együttes vállalása. A szórás azonban nagy. Az európai identitás a Benelux államokban élő emberek túlnyomó többsége számára ugyanúgy releváns, mint a nemzeti identitás. Legkevésbé Nagy-Britannia polgárai érzik magukat európainak, ami nyilván belejátszott a Brexit-népszavazás eredményének alakulásába (Striessnig-Lutz 2016).

Magyarországon az európai csatlakozást megelőző évtizedben végzett szociológiai kutatások azt mutatták, hogy a magyarok már akkor az EU elsődleges feladatai között tartották számon a nem európai menekültek beáramlásának megakadályozását. A csatlakozástól elsődlegesen gazdasági javulást vártak a válaszadók. A nemzeti szuverenitás alakulását illetően megoszlottak a vélemények. Voltak, akik szerint a csatlakozás ára a szuverenitás csorbulása, míg mások ezt a véleményt nem osztották. A jogbiztonság és a szabadságjogok érvényesülésére a többség garanciát látott a csatlakozásban. A csatlakozás várható egyenlegét megítélvén a megkérdezetteknek csak $9 \%$-a volt pesszimista, szemben a többséggel, akik egy része feltétlen optimista volt (32\%), más részük pozitív és negatív következményekre egyaránt számított (35\%). A megkérdezettek legkevésbé a nemzeti identitás és kultúra hanyatlásától tartottak, míg leginkább a bünözés térhódításától féltek. Az optimisták a 35 év alatti, idegen nyelvet beszélö, magas iskolai végzettséggel rendelkező, budapesti vagy nyugat-magyarországi lakhellyel rendelkező válaszadók között messze az átlag feletti arányban fordultak elö, míg a pesszimisták javarészt az alacsony iskolai végzettségű, munkanélküli, alkalmi munkából, segélyből, nyugdíjból élő, a Tiszától keletre élő válaszadók közül kerültek ki (Csepeli-Závecz 1997; Csepeli 1998).

Harminc év múltán, az Európai Unióba befogadva a magyar társadalom Európával kapcsolatos attitűdjei keveset változtak. Az Eurobarometer adatai szerint a magyar népesség zöme (79\%) előnyösnek látja Magyarország tagságát az Európai Unióban, s 60\% azok aránya, akik szerint a tagság jó dolog, míg a tagságban rosszat látók aránya csak $6 \%$. A 2019-ben esedékes európai parlamenti választások fő kampánytémáit a bevándorlás, a gazdasági növekedés és a biztonságpolitika kérdései határozzák meg.

A magyar fiatalok körében a legutóbb, 2016-ban végzett felmérés eredményei szerint a válaszadók 42\%-a tartotta elönyösnek Magyarország tagságát az Európai Unióban, míg négy évvel korábban ez az arány csak $30 \%$ volt. A saját élet perspektívájából nézve a vá- 
laszadók 38\%-a látta kedvezően a tagságot, ami a 2012-es helyzethez képest 8\%-os emelkedést mutat (Boros-Bozsó 2016).

$\mathrm{A} z$ Eurobarometer 2016-ban végzett felmerése szerint a 16-30 év közötti európai fiatalok 57\%-a peremre szorítva érzi magát. A hasonló korú magyar fiatal válaszadók 53\%-a hasonlóképpen érez. A változás lehetőségét az európai fiatalok 32\%-a abban látja, hogy más országban tanul, dolgozik majd a jövőben. A magyarok körében ez az arány 29\%. Egy két évvel korábbi, a fiatal korosztályokat reprezentáló mintán az Eurobarometer kutatói az Európai Unió előtt álló kihívásokról kérdezték meg a 28 tagállam fiataljait. Az eredményeket az 1. táblázaton mutatjuk be.

1. táblázat: Az EU előtt álló legfontosabb kihívások az európai fiatalok szerint 2014-ben (\%)

\begin{tabular}{lcc}
\hline & EU-átlag & Magyarország \\
\hline Munkanélküliség & 45 & 52 \\
Fiatalok munkavállalása & 27 & 38 \\
Társadalmi egyenlötlenségek & 23 & 18 \\
Bevándorlás & 20 & 15 \\
Nemzeti eladósodottság & 20 & 5 \\
Természeti erőforrások kimerülése & 17 & 15 \\
Öregedés & 16 & 27 \\
Adócsalás & 15 & 18 \\
Energiaellátás & 11 & 7 \\
Klímaváltozás & 15 & 12 \\
Terrorizmus & 10 & 11 \\
Verseny a feltörekvő országokkal & 10 & 5 \\
Az EU nemzetközi befolyása & 7 & 5 \\
Elégtelen növekedés & 4 & 5 \\
\hline
\end{tabular}

Forrás: European Youth in 2014. Flash Eurobarometer of the European Parliament EPEB395

A táblázatban közölt adatok szerint a magyar fiatalok az európai átlaghoz képest jobban aggódnak a munkanélküliség, a fiatalok munkavállalása és a kontinens lakosságának elöregedése miatt, viszont kevésbé foglalkoztatja őket a bevándorlás. Ez az eredmény arra figyelmeztet, hogy mielött Magyarországon kitört 2015-ben a bevándorlással kapcsolatos morális pánik, a magyar fiatalokat csak kis mértékben aggasztotta a bevándorlás.

$\mathrm{A} z$ „európai fiatalok” és a „magyar fiatalok” kifejezések természetesen absztrakciók, melyek szociológiailag heterogén csoportot jelentenek. A csoportot azonban homogenizálja, nemzedékké teszi a 21. század elején megszülető új Európa, mely nagyon más lesz, mint az az Európa, melyben szüleik és nagyszüleik felnőttek. Ma azonban még nem tudjuk, hogy milyen lesz az új Európa.

Gyurgyák János remek könyvéből megtudtuk, hogy a szabadság adta az erőt, mely Európát a világ élvonalába emelte és ott tartotta kétezer éven át. A szabadság adta erő azonban elapadt. A mai Európa demográfiai, gazdasági és politikai súlya a világ egészé- 
hez képest folyamatosan csökken. Az Eurobarometer kérdőívében felsorolt kihívások listája távolról sem teljes. Hiányoznak azok a kihívások, amelyek megfelelő válasz hiányában szétrobbanthatják az Európai Uniót. A 21. század elején az Európai Unió válaszúthoz érkezett. Az „ever closer Union” semmitmondó politikája nem ad választ az Uniót megalakulása óta kísértő kihívásra, melynek lényege, hogy az Unió a konföderációt vagy a föderációt válassza-e inkább. Az Eurobaromer kérdőíve ezt az alapvető kihívást nem tartalmazza. A kérdőívben felsorolt kihívások többségére adható megfelelő válasz attól függ, hogy az Európai Unió meg tud-e felelni a globalizáció által teremtett kihívásoknak. Ezekre a kihívásokra az Unió tagállamai külön-külön nyilvánvalóan nem képesek megfelelő válaszokat adni. Ez a felismerés azonban csak akkor válhat a változtatás erejévé, ha az egységesülés előnyeinek felismerése az egyes tagállamokban képes lesz elhallgattatni a nemzeti szuverenitás szirénhangjait, melyeket felerősít a populizmus és a xenofóbia.

$\mathrm{A} z$ Eurobarometer kérdőívében nem szerepel az Európát történelmileg megosztó Kelet-Nyugat kihívás sem. Az Európai Unió kibővülése sokakban azt a reményt keltette, hogy a 21. században betemetődik az Európát megosztó szakadék, a három európai fejlődési régió közötti különbségek mérséklődnek, majd eltűnnek.

2. táblázat: Európaiak értékválasztásai 2016-ban történeti fejlődési régiók szerint (átlagok)

\begin{tabular}{lccc}
\hline & Nyugat-Európa & Közép-Európa & Kelet-Európa \\
\hline Altruizmus & 0,83 & 0,54 & 0,32 \\
Univerzalizmus & 0,61 & 0,47 & 0,32 \\
Autonómia & 0,45 & 0,25 & 0,05 \\
Biztonság & 0,36 & 0,61 & 0,52 \\
Tradíció & 0,07 & 0,17 & 0,22 \\
Hedonizmus & $-0,13$ & $-0,69$ & $-0,34$ \\
Konformitás & $-0,29$ & 0,05 & $-0,17$ \\
Teljesítmény & $-0,49$ & $-0,29$ & $-0,20$ \\
Kockázatvállalás & $-0,67$ & $-0,70$ & $-0,67$ \\
Hatalom & $-1,00$ & $-0,70$ & $-0,23$ \\
\hline
\end{tabular}

A 2. táblázat az European Social Survey 2016-ban történt adatfelvétele alapján készült. $\mathrm{A} z$ adatfelvételben 22 európai ország és Izrael vett részt. Mindegyik országban az országos reprezentatív mintába került válaszadók vettek részt a vizsgálatban. A táblázatban a Salom Schwartz által kifejlesztett értéktesztre adott válaszok átlagait látjuk, régiónkénti bontásban. Az egyes országok régiók szerinti besorolásában Szűcs Jenő elméletét követtük. A nyugat-európai régióba soroltuk Ausztriát, Belgiumot, Svájcot, Franciaországot, Németországot, Hollandiát, az Egyesült Királyságot, Norvégiát és Svédországot. A közép-európai régióba soroltuk Csehországot, Magyarországot, Lengyelországot és Szlovéniát. A kelet-európai régiót egyedül az Orosz Föderáció lakói képviselték.

Schwartz Max Weber elméletét követve az értékekben jelöli meg a társadalmilag releváns cselekvések kiindító erejét, mely az individuumban hat, de a kollektívum teréből származik. Az értékek ezáltal hidat képeznek az egyének és a társadalom között. Schwartz rendszerében az értékek fontosságuk szerint rangsorolhatók, ami az egyes 
társadalmi csoportok közötti különbségek érzékeny jellemzését teszi lehetővé. Az értéktesztet magyar populációk vizsgálatai során is sikerrel alkalmazzák (Tóth 2009; Luksander-Mike-Csite 2010; Füstös 2010; Hankiss 1977).

Schwartz tesztje 21 különbözőképpen leírt ember rövid jellemzését tartalmazza. A válaszadók egy hatfokú skála segítségével fejezték ki, hogy a leírt portré hasonlít rájuk. Ezáltal a módszer kikerüli a direkt önjellemzések csapdákat (önigazolás, mimikri, önprezentáció) (Váriné 1987).

Schwartz a más kutatók (Inglehart, Rokeach, Hankiss) értékvizsgálati elgondolásait hasznosítva 10 értéktartományt különböztet meg, melyek mindegyikét a rövid jellemzésekkel szembesített válaszadónak minősítenie kell aszerint, hogy hasonlítanak-e rá, vagy tőle idegenek (Schwartz 1992). A 10 értéktartomány mindegyikét központi motivációk szervezik eggyé. Az értékeket és a hozzájuk tartozó központi motivációkat a következő táblán mutatjuk be.

Értékek és központi motivációk a Schwartz-tesztben

\begin{tabular}{ll}
\hline Értékek & Központi motivációk \\
\hline Autonómia & önálló gondolkodás és cselekvés, alkotás, fejlesztés \\
Stimuláció & izgalom, újdonság, kihívás az életben \\
Hedonizmus & öröm, kedvtelés \\
Teljesítmény & siker \\
Hatalom & státusz, kontroll emberek és erőforrások felett \\
Biztonság & harmónia, kockázatkerülés \\
Konformitás & normák tiszteletben tartása, engedelmeskedés \\
Tradíció & szokások, vallási hitek, hagyományok tisztelete \\
Altruizmus & együttérzés, szolidaritás a közeli kapcsolatban lévőkkel \\
Univerzalizmus & társadalom jóléte, környezet védelme, tolerancia, megértés \\
\hline
\end{tabular}

A központi motivációkra vonatkozó állításokkal mért 10 értéktartomány Schwartz rendszerében két egymásra merőleges tengely mentén négy értékcsoportban helyezkedik el.

Az első tengely egyik pólusán a változásra való nyitottság, másik pólusán a konzerválás helyezkedik el. A változásra való nyitottságot az autonómia, stimuláció és a hedonizmus képviseli, míg a konzerválás pólusán a biztonságot, a tradíciót és a konformitást találjuk.

Az első tengelyt keresztbe metsző második tengely egyik pólusán az individualizmust, másik pólusán az idealizmust találjuk. Az individualizmus feltétele a teljesítmény és a hatalom értékeinek elfogadása. Az idealizmus pólusán az altruizmus és az univerzalizmus értéktartományait találjuk. A Schwartz-teszt kitöltését követően a vizsgált populációk egésze, és a szociológiai változók által bontott csoportjai jól jellemezhetőek az innováció szempontjából kulcsfontosságú értékek megléte vagy hiánya által. Ráadásul az egyik érték igenlése a másik érték elfogadásával jár együtt, ami növeli a vizsgálati adatok érvényességét.

Az önállóság, a stimuláció, a hedonizmus a teljesítmény értékei innovációra hajlamosítanak, míg a biztonság, a konformitás, a tradíció az innovációnak nem kedveznek. A vá- 
laszadók által adott válaszok alapján a kérdőívben kérdezett minden érték egy [+1 -1] közötti tartományban helyezkedik el. Minél közelebb van a +1-hez a szám, annál fontosabb az adott érték, s minél közelebb van a -1-hez a szám, annál kevésbé fontos az adott érték.

A 2. táblázat tanulsága, hogy a Szűcs Jenő által oly plasztikusan leírt, a Római Birodalom felbomlását követően kialakult fejlődési régiók a lelkekben még ma is élnek (Szücs 1983). Feltűnő, hogy az altruizmus és az univerzalizmus értékei a nyugat-európai régióban élők számára jóval nagyobb súllyal esnek latba, mint Közép-Európában, nem is beszélve Kelet-Európáról (az utóbbi régiót az ESS vizsgálatban csak Oroszország képviselte). Hasonló a helyzet az autonómia értékének választása esetében. Az európaiság lényegét képező egyéni szabadság középkorig visszanyúló hagyománya mind a mai napig eleven Nyugat-Európában, szemben Közép- és Kelet-Európával, ahol az alattvalói mentalitás uralkodik, mely nem viseli el az autonómiát semmilyen formában (Csepeli-Prazsák 2011).

Másfelől beszédes, hogy a biztonság értéke a közép- és kelet-európaiak számára sokkal fontosabb, mint a nyugat-európaiak esetében. A biztonság mind Közép-Európában, mind Kelet-Európában a legfontosabb érték. A választás nem véletlen, nyilván összefügg azzal, hogy a közép-európaiak és a kelet-európaiak jóval nagyobb bizonytalanságban élnek, mint nyugat-európai polgártársaik.

Riasztó, hogy a teljesítmény és a kockázatvállalás értékei mindhárom régióban kiesnek a preferált értékek sorából. Ha ez nem változik, akkor Európa jövője a globális versenyben kérdéses lehet, hiszen teljesítménymotiváció és kockázatvállalás nélkül aligha születnek olyan gazdasági és szellemi teljesítmények, melyek a múltban Európát naggyá tették.

Érdemes megnézni, hogy miként alakultak a 16-30 év közötti fiatalok értékválasztásai 2016-ban Európában.A 3. táblázat adatai is az ESS felvételből származnak, értelmezésük során ugyanazt az elvet követjük, mint a 2. táblázatban. Érdemes megjegyezni, hogy a World Values Survey adatai szerint a magyarok értékválasztásaik szerint az évezred elején kívül kerültek az európai katolikus országok övezetéből, s átsodródtak az ortodox keresztény országok övezetének nyugati szélére (Inglegart-Welzel 2005).

3. táblázat: Fiatal európaiak értékválasztásai 2016-ban az EU 22 országában és Magyarországon

\begin{tabular}{lcc}
\hline & EU 22 & Magyarország \\
\hline Altruizmus & 0,71 & 0,24 \\
Autonómia & 0,45 & 0,37 \\
Univerzalizmus & 0,44 & 0,07 \\
Hedonizmus & 0,19 & 0,33 \\
Biztonság & 0,15 & 0,30 \\
Teljesítmény & $-0,17$ & 0,08 \\
Kockázatvállalás & $-0,21$ & $-0,15$ \\
Tradíció & $-0,28$ & $-0,36$ \\
Konformitás & $-0,60$ & $-0,61$ \\
Hatalom & $-0,89$ & $-0,29$ \\
\hline
\end{tabular}

Forrás: ESS 2016. Ciprus, Málta, Luxemburg, Dánia, Lettország nem vett részt a felmérésben 
A 3. táblázat azt mutatja, hogy a magyar fiatalok körében az altruizmus messze nincs az első helyen, szemben az EU-országok többségével, ahol az altruizmus a leginkább preferált érték. A magyar fiatalok európai kortársaikkal szemben a hedonizmust és a biztonságot preferálják. Fontos eredmény, hogy a teljesítményt a magyar fiatalok többre tartják, mint kortársaik Európában. A mai európai fiatalok teljesen más Európában fognak élni, mint szüleik és nagyszüleik. Ha nem lenne bevándorlás, az Európai Unió népessége fogyna. A bevándorlás visszafordíthatatlanul megváltoztatja Európa kulturális térképét. A különböző okok miatt az EU országait választó bevándorlók részaránya az egyes európai országokban folyamatosan emelkedik. Az arány még nagyobb, ha hozzászámítjuk az első generációs bevándorlók leszármazottait, akik a jelentős kulturális különbségek miatt integrációs nehézségekkel küszködnek.

A bevándorlók javarészt Európa északi és nyugati régióiba igyekszenek, Közép- és Kelet-Európa országait kerülik. A xenofóbia paradox módon azokban az országokban erősebb, ahol nem élnek számottevő arányban bevándorlók (Ágh 2016).

A régiók közötti különbség az Európai Unión belüli népmozgásokban is megmutatkozik. Elenyésző azok aránya, akik Nyugatról Keletre mennek. Ezzel szemben a szabad mozgás adta lehetőségekkel élve a közép- és kelet-európai régió országaiból folyamatosan érkeznek bevándorlók a nyugat-európai régió országaiba. Az alacsony születésszám, a viszonylag magas halálozási arány miatt Közép- és Kelet-Európa országaiban rohamosan fogy a népesség. A fiatalok, a képzettek, az idegen nyelven beszélők Nyugat-Európa országaiba mennek, hogy ott tanuljanak, dolgozzanak. A jövő Európája előtt álló legnagyobb kihívás, hogy a földrész megállja a helyét a globális gazdasági és szellemi versenyben. A 21. században várhatóan újra kell fogalmazni Európa jelentését. Az Ázsiából és Afrikából érkező bevándorlók megváltoztatják az európai társadalmak kulturális karakterét. A változások Nyugat-Európában várhatóan jóval jellegzetesebbek lesznek, mint Keleten, mélyítve a Kelet-Nyugat közötti szakadékot.

$\mathrm{A} z$ Európai Unió jogi személyiségét megteremtő maastrichti szerződés nagyon helyesen elismerte a nyugati civilizációban gyökerező emberi jogi és demokratikus prioritásokat, de szerencsétlen módon nem szentelt figyelmet az európai identitás kiépítésének, az életbe belépő európai fiatalok politikai szocializációjának.

$\mathrm{A} z$ Európai Uniónak csak akkor lesz jövője, ha létrejön egy egységes európai társadalomlélektani tér, mely lehetővé teszi, hogy felnevelődjenek az európai választópolgárok, akikben az európaiság érzése a nemzeti és regionális identitást nem tagadja, hanem kiegészíti. Alapvető fontosságú, hogy legyen egy közös nyelv, melyet minden európai ország iskoláiban tanítanak és a közbeszédben elfogadnak. Ez a nyelv nem lehet más, mint az angol. A Brexit megvalósulásával az angol nyelv előnye, hogy sehol nem anyanyelv, így nem válhat céltáblájává nyelvpolitikai harcoknak. Az angol már ma is Európa-szerte használatos nyelv, melynek ismerete jelentősen megkönnyíti az emberek és eszmék szabad áramlását az Európai Unió országaiban.

A minden európai országban azonos elvek alapján formált európai politikai szocializáció feladata, hogy a fiatalok „európai szemmel” nézzenek földrészükre, meglátva és megszeretve annak szépségeit, környezeti értékeit. Az európainak látott tájat európai emberek népesítik be, akik történeteit, örömeit és szenvedéseit megismerve a mindenkori jelenben élők önmagukat elhelyezhetik az európai térben és időben. Az európai történelmi és kulturális örökség megismertetése az európai politikai szocializáció legfontosabb 
feladata. A cél a szabadság, a kockázatvállalás, a teljesítmény értékeinek átmentése a jövő generációk számára.

\section{IRODALOM}

Ágh, A. (2016) The Rocky Road of Europeanization in the New Member States: From the Democracy Capture to the Second Try of Democratization. Polish Sociological Review, Vol. 193. pp. 71-86.

Boros L. \& Bozsó H. (2016) A vallási, a nemzeti és az európai identitás megítélése a 2016-os nagymintás ifúságkutatás adataiban. In: NAGy A. (ed.) Margón kivüll. Magyar Ifjúságkutatás 2016. Budapest, Excenter Kutatóközpont. pp. 204-236.

Csepeli Gy. (1998) Az Occidens-Express magyar utasai. Szabolcs-Szatmár-Beregi Szemle, Vol. 33. No. 1. pp. 54-58.

Csepeli Gy. (2016) A Z nemzedék lehetséges életpályái. Educatio, Vol. 25. No. 4. pp. 509515.

Csepeli Gy. \& Prazsák G. (2011) Az el nem múló feudalizmus. Társadalomkutatás, Vol. 29. No. 1. pp. 63-79.

Csepeli Gy. \& Závecz T. (1997) Várakozások, remények, félelmek: Az Európai Unió képe a magyar közvéleményben. In: Kurtán S., Sándor P. \& VAss L. (eds) Magyarország politikai évkönyve. Budapest, Demokrácia Kutatások Magyar Központja Alapítvány. pp. 650-668.

Füstös L. \& Szalma I. (2010) A változó értékrendszer 2. Magyarország értéktere - Európa értéktere. MTA SZKI, Budapest.

GyURGYÁK J. (2018) Európa alkonya? Utak és tévutak az európai történelemben és politikában. Budapest, Osiris.

Hankiss E. (1977) Érték és társadalom. Tanulmányok az értékszociológia köréböl. Budapest, Magvető.

Inglehart, R. \& Welzel, Ch. (2005) Modernization, Cultural Change and Democracy. New York, Cambridg University Press.

Luksander, A., Mike, K. \& Csite A. (2010) Maguk urai - a magyar vállalkozó lelkialkata. A magyarországi kisvállalkozók értékvilágának néhány jellemzője. TM. 67. Mühelytanulmány.

Schwartz, S. H. (1992) Universals in the Content and Structure of Values: Theory and Empirical Tests in 20 Countries. In: M. Zanna (ed.) Advances in Experimental Social Psychology, Vol. 25. pp. 1-65. New York, Academic Press. http://dx.doi.org/10.1016/ S0065-2601(08)60281-6 [Letöltve: 2018. 12. 08.]

Striessnig, E. \& Lutz, W. (2016) Strengthening of European Identity. Population and Demographic Review, Vol. 42. No. 2. pp. 305-311.

Szűcs, J. (1983) Vázlat Európa három fejlődési régiójáról. Budapest, Magvető.

Tóтн I. Gy. (2009) Bizalombiány, normazavarok, igazságtalanságérzet és paternalizmus a magyar társadalom értékszerkezetében. Budapest, Tárki. http://mek.oszk.hu/13400/13432/ [Letöltve: 2018. 12. 08.]

VÁriné Szilágy I. (1987) Az ember, a világ és az értékek világa. Budapest, Gondolat.

A cikk a Creative Commons Attribution 4.0 International License (https://creativecommons.org/licenses/ by/4.0/) feltételei szerint publikált Open Access közlemény, melynek szellemében a cikk bármilyen médiumban szabadon felhasználható, megosztható és újraközölhető, feltéve, hogy az eredeti szerző és a közlés helye, illetve a CC License linkje és az esetlegesen végrehajtott módosítások feltüntetésre kerülnek. (SID_1) 